\title{
O COLE e a leitura: em redor da crise
}

\section{COLE and reading: around the crisis}

https://doi.org/10.34112/2317-0972a2020v38n79p133-136

\section{Lilian Lopes Martin da Silva ${ }^{1}$}

SANTOS, Geniana. Políticas curriculares de leitura: crise, antagonismo e negociação no Congresso de Leitura do Brasil (COLE). Curitiba: CRV, 2019. 208p.

O Congresso de Leitura do Brasil (COLE) é uma realização da Associação de Leitura do Brasil (ALB) ${ }^{2}$, tendo sua primeira edição organizada pelo Departamento de Metodologia de Ensino da Faculdade de Educação da Unicamp em 1978. O evento integrou a movimentação da sociedade civil brasileira pela construção de um país democrático após a ditadura militar instalada em 1964.

Nessa primeira edição do Cole e em todas as outras que se sucederam nos 42 anos do evento e ainda hoje, o congresso apresenta e debate a prática da leitura, seja ela escolar ou não, sempre em fina sintonia com campos diversos de conhecimento e questões de seu tempo. Produz políticas de leitura, como pondera Santos (2019, p. 188) nesta obra que aqui apresentamos, "amplamente negociadas e disseminadas pelas comunidades epistêmicas e disciplinares entre o meio acadêmico e na formação de professores, impactando diretamente na produção de significação sobre a leitura no âmbito das práticas escolares”. Este livro, que relata e discute momentos

1. Universidade Estadual de Campinas, Campinas, São Paulo, Brasil.

2. ALB - acessível em: http://alb.org.br. 
de formulação de políticas nos Coles e suas ênfases, resulta de uma pesquisa desenvolvida como Doutorado em Educação na Universidade Estadual do Rio de Janeiro, em que Geniana dos Santos se confrontou cotidianamente, no contexto escolar, com a afirmação de que "meu aluno não lê". E foi em busca de compreendê-la, de desvendar como se construiu discursivamente a ideia de uma crise de leitura.

Partindo do pressuposto de que as políticas curriculares e também as de leitura - resultam não apenas de orientações e diretrizes centralizadas e verticalizadas, mas da produção e do debate de comunidades epistêmicas ou científicas, a obra investiga, entre outros documentos escritos (como produções acadêmicas e propostas curriculares), as discussões havidas nos Congressos de Leitura do Brasil (COLE), entendendo ser esse um importante espaço de produção, circulação e lutas de significações e paradigmas de leitura, que têm impactado as políticas curriculares e a formação de formadores de leitores.

O estudo está ancorado na perspectiva discursiva e pós-estrutural, tendo como referências principais autores como Homi Bhabha, Joan Leach, Ernest Laclau e Gemma Penn, em seus estudos sobre a cultura, o discurso, a retórica e as imagens. E também Alice Casemiro Lopes e Elizabeth Macedo, integrantes do grupo de pesquisa ao qual a autora estava vinculada e pesquisadoras do campo do currículo, com produção bastante expressiva.

Após passear por diferentes formações discursivas sobre leitura, livro, leitores, destacando as diversas significações assumidas por eles ao longo da história, a autora realiza a leitura e interpretação de documentos textuais verbais e imagéticos de duas edições específicas do Cole e toma-as como material empírico para sua análise: a 12. a, de 1999, cujo temário foi: "Múltiplos objetos, múltiplas leituras: afinal, o que a gente lê?" e a 16.a, de 2007, que teve por tema: "No mundo há muitas armadilhas e é preciso quebrá-las".

Antes, porém, apresenta uma narrativa dos Congressos anteriores, apontando os caminhos enfatizados e as concepções de leitura construídas nesse espaço discursivo, que são firmados a partir do inimigo ou "antagonista" a ser vencido: a crise de leitura. Tais caminhos vão do apelo à democratização às políticas de promoção do livro e da leitura; das possibilidades metodológicas e pedagógicas para o trabalho escolar à formação docente; das questões postas ao livro didático à ressignificação do espaço da biblioteca; da leitura literária à literatura infantil; etc.

O exame desse complexo discursivo em sua diacronia, assim como daquele referente ao material produzido e colocado em circulação no $12 .^{\circ}$ e no 16. ${ }^{\circ}$ COLEs, é vigoroso e detalhado. Com ele, e apoiada em seu quadro de 
referências, a autora constrói um percurso reflexivo em que é possível destacar para os leitores algumas ideias importantes.

A primeira delas é que o espaço de discussões, inaugurado pelo Cole em 1978 (e que vem se mantendo até hoje), demarcou um inimigo a ser vencido - ao qual denominou crise de leitura - através de um processo articulatório capaz de reunir e fazer circular posicionamentos críticos, em relação não só ao campo pedagógico, mas também aos campos cultural e educacional.

O segundo destaque a fazer diz respeito à relevância desse evento para a definição de políticas voltadas à promoção do livro e da leitura, especialmente as políticas curriculares. Reitera-se o caráter democrático do evento, que se configura em sua cadeia articulatória como espaço capaz de acolher inúmeras diferenças sobre o entendimento do que seja leitura, abrindo-se à negociação de múltiplos sentidos, enfatizados por diferentes campos de conhecimento, como a educação, a linguística, a teoria literária, a psicologia, etc.

Segundo o estudo, se inicialmente o Cole firmou-se através da luta pelo acesso ao livro e pela democratização da leitura, com o passar do tempo essa crise de acesso foi se transformando numa crise de qualidade de leitura, de formação para a leitura. Entretanto, "a identidade leitora baseada no acesso ao livro e à biblioteca tem sido elemento estável nas políticas de leitura mobilizadas pelo COLE” (p. 184).

Para a autora, a ideia de crise passou a ser desestabilizada no interior do próprio Cole, quando foi possível reconhecer - e se começou a enfatizar - a leitura como uma prática cultural possível de ser vivida em toda a sua diferença, por diferentes comunidades, numa clara orientação para a construção de um inventário de leitura, ao invés de se postular um projeto de formação. Dessa forma, outros sentidos tornaram-se possíveis.

Às preocupações com a formação do leitor na escola, tendo em vista sua aprendizagem, somaram-se aquelas relativas às questões que envolvem a textualidade e os suportes da leitura, e também outras, relativas à formação do aluno e do professor para a leitura literária e a formação humana, que envolvem valores estéticos e morais.

Um último destaque vai para a questão das metáforas, cujos sentidos, para a autora, são colonizadores. Em capítulo específico para tratar dos campos metafóricos da retórica colonial, Geniana discorre sobre o modo como a leitura tem sido representada. Nesse sentido discute expressões como: explorar, extrair, apropriar-se de um patrimônio ou repertório, dominar, descobrir... todas elas condensando sentidos de uma lógica mercadológica. 
Esse amplo universo de discursos, que, no Cole, disputam a hegemonia de sentidos, fez e faz emergir formulações sempre marcadas pelo hibridismo e pela abertura, resultantes de negociações que, ao não permitirem qualquer cristalização ou silenciamento, impedem a construção de um projeto uniforme e único para impulsionar a formação leitora.

Em tempos de centralizações e de arroubos de autoritarismo, vale a pena ler o livro aqui apresentado e conhecer, a partir dele, as produções que o Congresso de Leitura do Brasil vem colocando em circulação.

\section{SOBRE A AUTORA}

Lilian Lopes Martin da Silva é graduada em Linguística (Universidade Estadual de Campinas), tem Mestrado e Doutorado em Educação (Universidade Estadual de Campinas). É professora pesquisadora da Universidade Estadual de Campinas. Tem experiência na área de Leitura, ensino e história da leitura com pesquisa em temas correlatos.

E-mail: lilianl@unicamp.br.

Orcid: https://orcid.org/oooo-0oo2-7040-9878. 